\title{
Pigment Epithelium-Derived Factor
}

National Cancer Institute

\section{Source}

National Cancer Institute. Pigment Epithelium-Derived Factor. NCI Thesaurus. Code C101645.

Pigment epithelium-derived factor ( $418 \mathrm{aa}, \sim 46 \mathrm{kDa}$ ) is encoded by the human SERPINF1 gene. This protein is involved in the regulation of both cell proliferation and angiogenesis. 